\title{
Economic Study of Banana Marketing in District Fatehpur, Uttar Pradesh
}

\author{
Shivam, B.S. Sachan, Bhartendu Yadav", Ambrish Kumar Verma and \\ Vijyendra Vikram Bhardwaj
}

Department of Agril. Economics \& Statistics, CSAUA\&T, Kanpur, Uttar Pradesh, India

*Corresponding author: yadvbhartendu@gmail.com (ORCID ID: 0000-0001-6761-1760)

Received: $12-03-2021$

Revised: $20-05-2021$

Accepted: 14-06-2021

\begin{abstract}
Survey work was carried out with the sample of 50 farmers in five different villages of the Malwan block of Fatehpur district of U.P. were selected purposively and randomly keeping because of having the highest area under Banana cultivation in district Fatehpur and based on the increasing trend in the area under production and production of banana. Sample villages were taken, keeping in view that they fall in the banana-rich area, and also the samples resemble the entire population. Data analysis reveals that the producer's share in consumer's rupee is 35.52 percent and wholesaler's net margin 18.71 percent, and retailer's net margin 26.86 percent of the total marketing margin of banana in channel I. The channel II contractor's net margin is found 3.6 percent, wholesaler's net margin, 17.99 percent, and the retailer's net margin was 25.95 percent of the total marketing margin of banana in the study area.

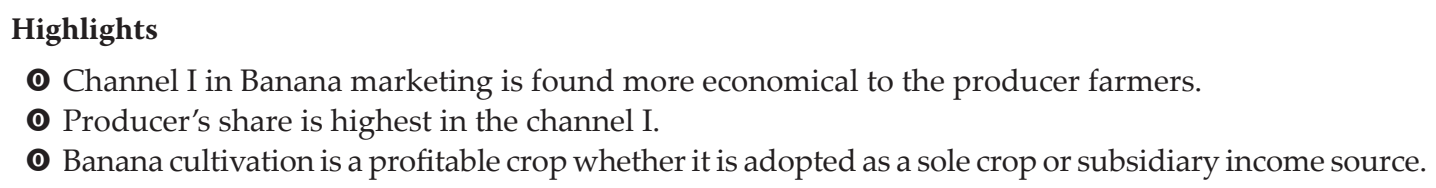

Keywords: banana, marketing, price spread, consumer surplus, marketable surplus

Banana is highly nutritious and widely consumed both as vegetable and fruits (Annual report, NCRB, 2020). Banana is reported to be grown in 130 countries in the world with a total production of 116 million tonnes in 2019 (mordorintelligence.com). India, China, the Philippines, Brazil and Ecuador alone produced more than 60 per cent of total world banana production (statista.com). Banana is the largest produced and maximum consumed amongst the fruits cultivated in India. India ranks first amongst the banana cultivating countries of the world with an annual production share of 27.74 per cent of the total harvest. India ranks first in banana production contributing about $23.00 \%$ in world pool of banana production (nhb.gov.in). Due to population expansion, higher purchasing power and development of new markets, demand for banana is increasing at a faster rate. U.P. rank $5^{\text {th }}$ in banana production contributing about $10.31 \%$ in India of banana production (agriexchange.apeda. gov.in). The major banana producing districts in U.P. are Siddarthnagar, Gorakhpur, Kushi Nagar, Fatehpur, Kausambi, etc. Fatehpur rank third in banana production of U.P (krishijagaran.com). The area under banana in Fatehpur district in Uttar Pradesh is about 7.75 thousand hectare and the production are 366.34 thousand metric tons.

Despite such achievements in the country, the producer's share in consumer's price largely depends

How to cite this article: Shivam, Sachan, B.S., Yadav, B., Verma, A.K. and Bhardwaj, V.V. (2021). Economic Study of Banana Marketing in District Fatehpur, Uttar Pradesh. Economic Affairs, 66(2): 343-347.

Source of Support: None; Conflict of Interest: None (क) 
upon the method of sale and the channels through which the produce reaches the ultimate consumers. At present the development of the agriculture does not merely depend upon increasing the agricultural produce and productivity, but also upon the promotion of a better and well organised marketing by which the agricultural goods are moved from the field of the farmer to the places of ultimate consumers (Vincy, 2016). Other things remaining the same, the larger the chain of intermediaries between producer and seller, the lesser will be the share of the producer, because a major part of the profit was share of the intermediaries. Marketing efficiency will be more in the market with less intermediaries involved (Sangolkar, 2012). The role of the commission agents cannot be eliminated totally; but needs to be minimized (Deshmukh et al. 2013). Due to forced sale and having poor storage facilities, the producers generally get a small share as profit for their produce. Keeping in view above drawbacks, the present study is performed to study the status of the market associated with the title, "economic study of banana marketing in district Fatehpur, U.P." with following objectives:

1. To workout the marketing cost and price spread under different marketing channels.

2. To work out the marketable surplus and producer's share in consumer's consumer's rupee under different marketing channels.

\section{METHODOLOGY}

The methodology deals with the modus operandi aspect of the study. The methodology of the present study entitled "Economic study of banana marketing in district Fatehpur, Uttar Pradesh", discussed under the following heads:

1. Sampling Technique

2. Method of enquiry and collection of data

3. Period of enquiry

4. Analytical tools used

A multi stage purposive sampling technique is adopted to select the district, block, villages and the cultivators. The details of the sampling technique at various stages are discussed here. District Fatehpur is selected purposively because of higher concentration of Banana cultivation in the district and following an increasing trend of production and productivity. Out of thirteen blocks of district Fatehpur, one block namely Malwan is selected purposively due to possessing the highest area under Banana cultivation in district Fatehpur. A list of all the villages growing Banana crop is prepared from the selected block Malwan. Five villages namely Maharaha, Kalyanpur, Janta, Jaitikheda, Gureer are selected randomly. A list the Banana growers according to their size group the selected village is prepared. The size groups were marginal (0-1ha), small (1-2ha) and large (2\& above ha.). Ten farmers are selected at random process from each village in proportion to their numbers falling under each size group. Thus, in all, 50 farmers are selected from the 5 villages falling under Malwan block in district Fatehpur. A market namely Jwalganj fruit mandi is selected purposively where maximum Banana fruit sold \& bought for the present study. A list of all the market functionaries of the selected mandi is prepared out of which 10 per cent were interviewed for the purpose of present enquiry. 25 Banana producers who brought their produce in the selected mandi for disposal are interviewed to find out the marketing cost marketing margin and producer's share in consumer's price. The enquiry is conducted by survey method. The primary data is collected by personal interview with respondents with the help of well-prepared schedules and questionnaires. During the course of investigation, several visits are made for collecting officers etc. is sought for obtaining the correct and reliable data. The secondary data are compiled from the records of the following authorities as well as published reports and Journals. Viz, Block Development Officer, respective Village Development Officer, District Statistical Office, District Horticulture Officer, Census report Index year 2011, District Agriculture Marketing Office Fatehpur.

The following statistical tools are used in the analysis and interpretation of data collected.

Tabular analysis is done to compare different aspect of farm business and marketing cost on different categories of the selected Banana growers and marketing mandi. The average referred to the average of aggregate value. The simplest and the most important measure of average is weighted mean which is used to compare the data in thesis. The formula used to estimate these averages is given below: 
Weighted Mean $=\sum W x_{1} / \sum W$

where,

$\mathrm{W}=$ weight of $x_{1}$

$x_{1}=$ Value of an item

\section{RESULTS AND DISCUSSION}

\section{Results}

The producer's share in consumer's price largely depends on the sale method and the channels through which the produce reaches the ultimate consumers. Other things remaining the same, the larger the chain of intermediaries between producer and seller, the lesser will be the share of the producer, because a major part of the profit was share of the intermediaries; Due to forced sale and having poor storage facilities (Nayak et al. 2018). The producers generally get a small share as profit for their produce.

An attempt has been made to study the different marketing channels through which producer sales his marketable surplus. The producer's share in consumer's price / rupee, marketing cost of banana, and middle men's marketing margins like contractor, wholesalers and retailers have also been worked out. In the study area the following channels of banana were found under operation.

- Channel-I: Producer - Wholesaler - Retailer Consumer

- Channel-II: Producer- Contractor-WholesalerRetailer-Consumer

\section{Channel - I: Producer - Wholesaler - Retailer - Consumer}

In this channel the producers directly sale their produce to wholesaler who sales to retailer in town and city and in last to consumers.

\section{Channel-II: Producer-Contractor-Wholesaler- Retailer - Consumer}

In this channel the producers directly sell their produce to contractor than who sales to wholesaler who sales to retailer in town and city and in last to consumers.

The marketing surplus of banana on the different size groups of holdings has presented in Table 1.

Table 1 reveals that marketable surplus decrease with increasing the size of holding i.e., 20763 quintals (0-1 ha), 19165.91 quintals (1-2 ha) and 18066.05 quintals ( 2 and above).

Table 2 reveal that producer's share in consumer's rupee is lowest being 33.56 per cent in channel II, it

Table 1: Marketable surplus under different size groups

\begin{tabular}{lllll}
\hline \multirow{2}{*}{ Particulars } & \multicolumn{4}{c}{ Size group of farms } \\
\cline { 2 - 5 } & $\mathbf{0 - 1}$ & $\mathbf{1 - 2}$ & \multicolumn{2}{c}{ 2 \& Above } \\
\hline Total area under banana (in ha) & 25 & 22.03 & 20.02 & 22.35 \\
Total production (in q) & 20775 & 19174.91 & 18072.05 & 19399.8 \\
Total quantity consumed by growers (in q) & 12 & 9 & 6 & 8.47 \\
Marketable surplus (in q) & 20763 & 19165.91 & 18066.05 & 19391.33 \\
\hline
\end{tabular}

Table 2: Price spread and marketing charges for different channel of banana/quintal

\begin{tabular}{|c|c|c|c|c|c|}
\hline \multirow{2}{*}{ S1. No. } & \multirow{2}{*}{ Particular } & \multicolumn{2}{|c|}{ Channel I } & \multicolumn{2}{|c|}{ Channel II } \\
\hline & & ₹/qt. & Per cent & ₹/qt. & Per cent \\
\hline 2 & Charges paid by producer & 75 & 2.59 & 00 & 00 \\
\hline 4 & Marketing cost incurred by contractor's & - & - & 35 & 1.21 \\
\hline 5 & Contractor's net margin & - & - & 105 & 3.60 \\
\hline 6 & Purchase price of wholesaler & 1100 & 38.12 & 1110 & 38.40 \\
\hline 9 & Purchase price of retailer & 1940 & 67.24 & 1950 & 67.47 \\
\hline 10 & Marketing cost incurred by retailer & 170 & 5.89 & 190 & 3.80 \\
\hline 11 & Retailer's net margin & 775 & 26.86 & 750 & 25.95 \\
\hline 12 & Purchase price of consumer & 2885 & 100 & 2890 & 100 \\
\hline 13 & Price spread & 1860 & 64.47 & 1920 & 66.43 \\
\hline
\end{tabular}


was 35.52 per cent in channel I in banana marketing on sample farms. The lower producer's share in the price paid by the consumer is due to higher marketing cost and marketing margins of profit charged by the middleman.

Marketing cost incurred by retailer per quintal came to ₹ $170(5.89 \%)$ in channel I and ₹ 190 (3.80\%) in channel II, respectively.

Retailer's net margin came to ₹ 775 (26.86\%) and ₹ 750 (25.95\%) channel I and II, respectively. Total marketing cost incurred by wholesaler per quintal came to ₹ 300 (10.39\%) and ₹ 320 (11.07\%) in channel I and II, respectively. Total marketing margin of wholesaler came to ₹ 540 (18.71\%) and ₹ 520 $(17.99 \%)$ in channel I and II, respectively. Marketing cost incurred by contractor per quintal came to ₹ 35(1.21\%) in channel II. Contractor's net margin came to ₹ 105 (3.6\%) in channel II. Price spread came to Rs.1860 (64.47\%), ₹ 1920(66.43\%), in channel I, and II, respectively.

\section{Discussion}

There are three marketing patterns was identified for banana marketing in the study area:

(i) Producer to consumer, this channel is better than all the marketing channels because, in this channel cultivator directly sales his produce to the consumers.

(ii) Producer-wholesaler-retailer-consumer, In this channel the producers directly sale their produce to wholesaler who sales to retailer in town and city and in last to consumers.

(iii) Producer-contractor-wholesaler-retailerconsumer, in this channel the producers directly sale their produce to contractor than sales to wholesaler who sales to retailer in town and city and in last to consumer.

In channel I (Producer-Whole Seller-RetailerConsumer) is very economical but in less adoption. The producer's share in consumer's rupee is 35.52 per cent. In channel I there are two intermediaries like wholesaler and retailer involved. Wholesaler's net margin 18.71 per cent and retailer's net margin 26.86 per cent of total marketing margin of banana. In channel II there are three intermediaries like contractor, wholesaler and retailer involved. Contractor's net margin 3.6 per cent, wholesaler's net margin 17.99 per cent and retailer's net margin 25.95 per cent of total marketing margin of banana. To improve above fallacies, Government should evolve a mechanism for rapid dissipation of marketing information using electronic systems, to make producers aware of marketing trends (Deshmukh et al. 2013).

Highest producer's share in consumer's rupee 35.52 per cent is obtained through channel I followed by 33.56 per cent by channel II in marketing channel of banana during the study period.

\section{CONCLUSION}

Currently, India stands first in the list of the maximum banana producing countries of the world. Banana area is distributed in 20 states. Among the states from India, Uttar Pradesh has significant contribution. From the findings it is concluded that channels involved in marketing of agricultural produce lowers the producer's income. In any agriculture rich country where farmers have the sole income source of farming only should have the easy and liberal management system to assist their final returns. Above results shows the drawbacks of the marketing system in the Fatehpur district. Producer to consumer can give the original smart returns to the farmer directly but is not practically possible everywhere. Channels provided in the marketing system are less or more advisable to adopt. Here, inclusion of the middle men make fall in the producers share. Channel I have the maximum producer share of 35.52 per cent, which could be further enhanced by implementing better marketing practices. The more the intermediaries are involved, the lesser will be the share in the producer's pocket. So, policy should be sound and straightforward enough to operate and application without disturbing the farmers' income. It should also focus on product diversification and marketing practices. Improvement in domestic market channels would increase efficiency in market transportations and market transportations and help maintain quality of the produce. Therefore, apex should always look into improving the country's marketing system by making the lesser involvement of the intermediaries in the market procedures at the ground level. 


\section{REFERENCES}

Agro-Economic Research, University of Madras "Marketing of Fruits and Vegetables in and around Chennai“, Agricultural Situation in India, 11(7): 475-478, 2003.

Anonymous 2014 a. Indian Horticulture Database. National Horticulture Board, Ministry of Agriculture, Government of India, New Delhi, pp. 38.

Anonymous 2013-14 b. Reports on fruits cultivation in India. Statistical Department of Agriculture \& Co-operation, GOI, 2013-2014.

Deshmukh, D.S., Bornare, Prashant P. and Anawade, P.K. 2013. Constraints in Banana Marketing and Scope of Improvement: A case study for Jalgaon Region, Int. J. Sci. Spirit. Bus. Technol., 2(1): 74-78.

Ghimire, S., Koirala, B., Devkota, S. and Basnet, G. 2019. Economic analysis of commercial banana cultivation and supply chain analysis in Chitwan, Nepal, J. Pharmacogn. Phytochem., SP5: 190-195.

Kumari P., Ahmed, N. and Wadhwani, M.K. 2017. An economic assessment of banana production in Bhagalpur district of Bihar. Hort. Flora Res. Spectrum, 6(2): 82-87.
Mallick, J., Das, N., Roy, K. and Mazumdar, S. 2020. An overview of various types of Banana production and its market value in India. Int. Res. J. Eng. Technol., 7(12): 1195-1204.

Nayak, A.K., Singh, N. and Kumar, D. 2018. An economic analysis of marketing of Banana in Durg district of Chhattisgarh. Int. Res. J. of Agril. Econ. Stat., 9(1): 1-8.

Phulara, G., Budha, J., Puri, C. and Pant, P. 2020. Economics of Production and Marketing of Banana in Kailali, Nepal. Food Agribusiness Manag., 1(1): 43-46.

Sangolkar, U.B. 2012. A study of Banana Production and Marketing in Wardha district of Maharashtra. Int. Res. J. Agril. Econo. Statistics, 3(1): 72-76.

http://www.fao.org/3/a-i6917e.pdf (April 15, 2021., 9:30 A.M.)

Gayatri, P., Janaki, B., Chiranjibi, P. and Prakash, P. 2020. Economics of Production and Marketing of Banana in Kailali, Nepal. Food E Agribus. Mgt., 1(1): 43-46. 
